\title{
NEIGHBOURS, BUSINESS PARTNERS, VICTIMS: JEWISH-CHRISTIAN INTERACTION IN AUSTRIAN TOWNS DURING THE PERSE- CUTIONS OF THE FOURTEENTH CENTURY
}

Eveline Brugger*

The beginnings of Jewish life in Austria were overshadowed by violence: Schlom, the first Jew whose presence in Austria can be proven and 1 who held the prestigious office of Master of the Mint for the Austrian Duke, was killed in his own house in Vienna by crusaders in $1196 .{ }^{1}$ However, the Duke's swift punishment of the murderers (the two leaders of the mob who killed Schlom and his family were executed) suppressed any further anti-Jewish outbreaks. The thirteenth century generally became a relatively peaceful and prosperous time for the Austrian Jews. Jews and Christians lived next to each other, which is evident from the records of house ownership in the cities, and social contacts were an everyday reality. ${ }^{2}$

The frequent repetition of demands made by Church authorities that the Jews were to live separated from Christians can be seen as an indication that such a separation was not happening de facto. At the Council of Vienna in 1267,

* Research for this article was funded by the Austrian Science Fund (FWF): P21236-G18.

${ }^{1}$ Brugger and Wiedl, Regesten zur Geschichte, I, 17-18, no. 4.

2 On the beginning of Jewish settlement in Austria during the thirteenth century, see Brugger, 'Von der Ansiedlung', pp. 127-29. On Jewish house ownership, see Lohrmann, Judenrecht und Judenpolitik, pp. 167-71. The earliest non-Jewish source mentioning a Jewish house in an Austrian city dates from 1235, when the monastery of Reichersberg redeemed a pledge from the Jew Teka and his Christian business partners in Teka's house in Vienna: Brugger and Wiedl, Regesten zur Geschichte, I, 24, no. 11.

Eveline Brugger (eveline.brugger@injoest.ac.at), research fellow at the Institute for Jewish History, St Pölten, Austria, and lecturer at the Universities of Salzburg and Graz

Intricate Interfaith Networks in the Middle Ages: Quotidian Jewish-Christian Contacts, ed. by Ephraim Shoham-Steiner, HDL 5 (Turnhout: Brepols, 2016)

pp. $267-286$ BREPOLS PUBLISHERS

10.1484/M.HDL-EB.5.112705 
the papal legate Guido issued a number of anti-Jewish restrictions, which were for the most part based on canons of the Fourth Council of the Lateran (1215). Among other restrictions, Jews were prohibited from frequenting Christian inns and bathhouses and from employing Christian servants; Christians were prohibited from sitting at the table together with Jews, from celebrating and dancing with them. ${ }^{3}$ Only seven years later did a synod in Salzburg issue a complaint about the common disregard of Guido's instructions; in 1284, a provincial synod in St Pölten repeated the restrictions from 1267, which can also be interpreted as an indication that they were widely ignored. ${ }^{4}$ This assumption is backed by rabbinical complaints about the same issue; clearly, each side feared that religious indoctrination by the other group might be a result of too-close social contacts. ${ }^{5}$

During the thirteenth century, Jewish settlement spread in the duchy of Austria: Jewish communities developed in some of the larger cities and towns, but there is also mention of Jews living in small rural villages. We know very little about everyday Jewish-Christian interaction in those villages, where the Jewish population often consisted of no more than one family, but it is safe to assume that contacts were even closer there out of sheer necessity. ${ }^{6}$

Most of the Christian sources on Jews from this period stem from business transactions, which is hardly surprising considering that the Austrian dukes strongly encouraged Jewish business, particularly financial business, in their territory. In 1244, Duke Frederick II granted the Austrian Jews a privilege that became the legal basis for Jewish life in Austria for the next centuries: the life, religion, and property of the Austrian Jews were strongly protected by the Duke, under whose direct jurisdiction the Jews were placed. However, the privilege made it clear that as far as the Duke was concerned, the only desirable occupation for Jews in Austria was the money business. ${ }^{7}$ Other occupations are not even mentioned in the charter - not because they did not exist or were not permitted, but because they were of no interest to the Duke. ${ }^{8}$

${ }^{3}$ Brugger and Wiedl, Regesten zur Geschichte, I, 59-61, no. 45. On the topic of Jews participating in Christian celebrations, especially weddings, see Wenninger, 'Nicht in einem Bett'.

${ }^{4}$ Brugger and Wiedl, Regesten zur Geschichte, I, 79, no. 65.

${ }^{5}$ Brugger, 'Von der Ansiedlung', pp. 205-06; Keil, 'Nähe und Abgrenzung', p. 7.

${ }^{6}$ Elukin, Living Together, Living Apart, pp. 84-85; Toch, Die Juden im mittelalterlichen Reich, pp. 40-43.

${ }^{7}$ Brugger and Wiedl, Regesten zur Geschichte, I, 35-37, no. 25; Brugger, 'Von der Ansiedlung', pp. 138-40; Lohrmann, Judenrecht und Judenpolitik, pp. 53-80.

${ }^{8}$ Chazan, Reassessing Jewish Life, p. 124. 
Based on the 1244 charter, the Austrian dukes granted their Jews protection and favours. In exchange, the Jews had to pay substantial taxes and put up with ducal control of their business, since the Jewish population legally belonged to the Kammer, that is, the duke's treasure. ${ }^{9}$ During the thirteenth century, this arrangement seems to have proved mutually satisfactory; as of the middle of the century, there are numerous business charters that show Jews doing business with noblemen, monasteries, and the inhabitants of both cities and rural communities.

It is of crucial importance for any study of the history of Jews in Austria to include these sources. Narrative sources, mostly chronicles and annalistic texts, focus on the remarkable or extraordinary events and tend to overlook the mundane. ${ }^{10}$ Therefore, the narrative sources are the most important type of sources on the topic of persecutions and anti-Jewish violence. The 'normal' everyday relations between Jews and Christians did not make their way into the chronicles, but they can be deduced from charters concerning loans, pawning, buying and selling of land and goods, legal disputes, and matters of inheritance, because they were results of direct Jewish-Christian interaction.

At first, this type of source mostly resulted from contacts between the Christian and Jewish social elites; written sources concerning lower-class business transactions became more numerous only in the course of the fourteenth century. This does not mean that Jewish-Christian business relations were restricted to the upper social classes of both groups in this period, but only that the smaller business transactions (pawnbroking and short-term loans for small sums of money) were not yet considered important enough to warrant a written record. ${ }^{11}$ However, the legal documents on Jewish moneylending that the dukes of Austria issued from the middle of the thirteenth century onwards indicate that the 'smaller' pawnbroking business was the norm, not the exception: in the aforementioned first ducal privilege for the Austrian Jews, ten of the thirty-one paragraphs dealt with pawnbroking, while only one touched upon bigger credit transactions between Jews and Christian noblemen.

${ }^{9}$ Lohrmann, Judenrecht und Judenpolitik, pp. 42-46; Patschowksy, 'Das Rechtsverhältnis', pp. 344-45; Toch, Die Juden im mittelalterlichen Reich, pp. 49-50, 106-07.

${ }^{10}$ Chazan, Reassessing Jewish Life, p. 182.

${ }^{11}$ Brugger and Wiedl, '...und ander frume leute genuch', pp. 290-91. Debt inventories, court records, and similar sources which shed light on smaller Jewish business transactions in other parts of Europe did not (yet) exist in Austria at the time. See, for example, Jordan, 'Jews on Top', pp. 39-42; Holtmann, 'Jewish Moneylending', pp. 305-06. On the development of economic serial sources in Austria, see Wiedl, 'Juden in österreichischen seriellen Quellen'. 
The surviving business charters (mostly issued by Christians) are free from anti-Jewish statements, which is hardly surprising given that they were usually handed over to the Jewish creditors until the loan was repaid. ${ }^{12}$ Jews could give testimony or act as arbiters together with Christians and were granted the same honorifics, such as 'honourable' or even 'pious' men, as their Christian counterparts. ${ }^{13}$ However, Hebrew charters (or Hebrew notes on German or Latin charters), which were incomprehensible to Christians, sometimes contained insider jokes at the expense of Christian business partners, no matter how highranking they were. ${ }^{14}$

Following the first known accusation of Jewish Host desecration that was raised in Paris in 1290, ecclesiastical sources record the first such accusations, as well as those of ritual murder, against Jews in Austria towards the end of the thirteenth century. ${ }^{15}$ The first persecution of Jews in Austria that went beyond an attack against a single person or family occurred in 1294, in the small Lower Austrian town of Laa an der Thaya, where Jews were accused of having stolen a Host wafer. ${ }^{16}$ Following the events in Laa, alleged Host desecration became the most frequent reason for outbreaks of anti-Jewish violence in late medieval Austria, whereas accusations of ritual murder were more common in other territories in the south of the empire. ${ }^{17}$

In 1305, a bloodied Host wafer was found near a Jewish house in the town of Korneuburg (near Vienna), and ten Jews - most likely the entire Jewish population of the town - were burned by the citizens. The incident was followed by a lengthy examination by the Church authorities, although they were less interested in the fate of the Jews than in the alleged miracles the Host wafer

12 On Austrian Jewish business charters in general, see Brugger and Wiedl, '... und ander frume leute genuch', pp. 295-97; Brugger, 'Urkunden zum jüdischen Kreditgeschäft im mittelalterlichen Österreich', pp. 69-77; Brugger, '... hat ein hebraisch zettel dabey’.

13 Wiedl, 'Jews and the City', p. 289.

${ }^{14}$ See, for example, Brugger and Wiedl, Regesten zur Geschichte, II, 11-12, no. 460 (translation by Martha Keil): The Viennese Jew Shalom and his wife Ester sold a vineyard to the knight Jeschk Pehaym and his wife Diemut. In the Hebrew charter issued by Shalom and Ester about the transaction, Diemut is not called 'wife' but ashpato, 'quiver' - a salacious quip based on the common use of arrow-based euphemisms for male sexuality; see, for example, Goldin, Jewish Women in Europe, p. 126.

15 Wiedl, 'The Host on the Doorstep', p. 312.

${ }^{16}$ Brugger and Wiedl, Regesten zur Geschichte, I, 89, no. 82.

${ }^{17}$ Langmuir, Toward a Definition of Antisemitism, pp. 120-33, 263-81; Lotter, 'Hostienfrevelvorwurf und Blutwunderfälschung', pp. 536-48; Rubin, Corpus Christi; Erb, 'Zur Erforschung'; Yuval, Two Nations in your Womb, pp. 170-73. 
had worked. The minutes of this examination, including the testimonies of witnesses, have been preserved and allow unique insights into the situation of a small number of Jewish inhabitants in a Christian town and the social networks which could be helpful to Jews, but also put them in immediate danger. ${ }^{18}$

Some of the witnesses said that the bloodstained Host had been found on the threshold of a house that belonged to the Jew Zerkel. Other witnesses claimed that they had seen Zerkel and some other Jews chase after a Christian who, according to the Jews, had thrown the Host into Zerkel's house. One of the Jews, a scholar (scholasticus), who was holding the Host in his hand, reportedly said to the Christian bystanders, 'Here, take your God, who was brought into my house by this servant, who should be burned rather than us'. Since nobody would take the Host from him, he then threw it on the ground, and Zerkel allegedly trod on it.

The Jewish scholar was the first to fall victim to a lynching mob: he was burned by a tumultuous crowd. Before his death, he reportedly confessed that Zerkel had bought the Host three years earlier from a Christian and that Zerkel had later tried to bribe another Christian to get rid of it for him, which the Christian refused. This story was corroborated by the testimony of the priest Konrad, vicar of Leobersdorf, who claimed that the person who had sold the Host to the Jews had told him about it during confession, which meant the priest could not reveal the name of the thief.

The witness Heinrich Shem also mentioned that two Christian citizens had taken Zerkel to the house of another citizen, Konrad Reus, in an attempt to save Zerkel from the people's wrath. However, when the mob that had burned the scholar returned and spread the tale of the alleged confession, the crowd entered Konrad Reus's house and beat Zerkel to death. It seems that Zerkel, most likely the head of the small Jewish community, had been given shelter by his neighbours, although they were not able to protect him against the fury of the crowd later. The identity of the other Jewish victims is not disclosed in the minutes of the interrogation. A few years later, the head of the ecclesiastical commission of inquiry, the Cistercian monk Ambrose from the Lower Austrian monastery of Heiligenkreuz, based his theological treatise Tractatus de hostia mirificata on the events of Korneuburg, but the treatise only men-

${ }^{18}$ For a complete transcript of the examination minutes, see Brugger and Wiedl, Regesten zur Geschichte, I, 125-42, no. 133. On the Korneuburg persecution in general, see Brugger, 'Von der Ansiedlung', pp. 211-16; Avneri, Germania Judaica, II.1, 450, II.2, 894; Rubin, Gentile Tales, pp. 57-65; Stelzer, 'Am Beispiel Korneuburg', pp. 313-14, 328-40; Wiedl, 'The Host on the Doorstep', pp. 299-346. 
tions that 'X personas ex iudeis virorum et mulierum' were burned. ${ }^{19}$ Since the examination minutes repeatedly refer to Zerkel's house as 'domus iudeorum' (indicating that it was the only Jewish residence in Korneuburg at the time), it is likely that all victims were members of Zerkel's household.

The testimonies illustrate clearly that at least some of the witnesses had known the Jews personally. Heinrich Shem stated in his testimony that Zerkel had addressed him by name when he told him that someone had thrown the Host into his house and then ran away. There is no record of any trouble between Jews and Christians in Korneuburg prior to 1305, yet all the witnesses expressed their firm belief that the Jews were indeed guilty of Host desecration. ${ }^{20}$ Peer pressure may have played a role in that: Heinrich Shem, for example, admitted that he had advised Zerkel to flee and even spoke of the hope (spes) that Zerkel might evade the citizens' wrath, but he was careful to point out in his testimony that he had told the Jew in no uncertain terms that he considered him guilty and was horrified by his crime. Unfortunately, Konrad Reus, the citizen into whose house Zerkel had been brought, was not among the witnesses, nor is it even clear whether he was present during the events that took place in his house. His wife, who according to another witness had been present at the discovery of the Host wafer in the Jew's hand, was interrogated, but was merely asked the standard questions that focused on the alleged miracles; at no point during the interrogation was it mentioned that Zerkel had been brought into her husband's house to keep him safe. It would be interesting to know if there were any repercussions against Konrad Reus (or the two citizens who took Zerkel to his house) in the wake of the anti-Jewish outbreak and the following veneration of the 'miraculous Host of Korneuburg', but the minutes of the interrogation do not indicate it. This is somewhat surprising considering that Ambrose of Heiligenkreuz later complained in the preface to his aforementioned treatise Tractatus de hostia mirificata that the citizens accused him of being in favour of the Jews because of his lengthy and thorough investigation of the events. ${ }^{21}$ Since Ambrose felt the need to justify himself against these

19 Brugger and Wiedl, Regesten zur Geschichte, I, 144-46, no. 135.

${ }^{20}$ It is safe to assume that the people of Korneuburg knew about the alleged Host desecrations which had led to the 'Rintfleisch' persecutions, a wave of pogroms against the Jews in and around Franconia in 1298. Lotter, 'Hostienfrevelvorwurf und Blutwunderfälschung,' pp. 548-60; Müller, 'Erez gezerah', pp. 251-54.

21 'Exorto quoque contra me odio civium prefatorum, quasi ego apponerem iudeis et processum negocii impedirem, reversus sum ad claustrum, et pro excusacione mea sequens opusculum compilavi': Brugger and Wiedl, Regesten zur Geschichte, I, 144, no. 135. 
accusations, it seems unlikely that the frequent expression of anti-Jewish sentiments in the witness accounts was due to the fact that the citizens did not want to look pro-Jewish to the ecclesiastical investigators; rather, the citizens' main motivation seems to have been the wish to have 'their' miraculous Host confirmed by the Church, which could only happen if the Jews' guilt was no longer in question.

Although Ambrose's treatise is focused on the 'miraculous Host wafer' and the legal question of whether the Jews of Korneuburg should really have been killed, it also mentions that the real culprit was discovered after the events of 1305: a priest from Korneuburg confessed to the Bishop of Passau that he had dipped an unconsecrated wafer into goat's blood and placed it on the threshold of Zerkel's house. Furthermore, he had conspired with four other Christians to 'prove' the Jewish Host desecration, which makes it seem very likely that some of the witnesses whose testimony is on record were collaborating with him. ${ }^{22}$ Ambrose even states that this confession correlates with the statements of two of Zerkel's neighbours, who had testified that they had seen three Jews chasing a fleeing man while shouting that he had thrown a Host wafer into their house.

The priest's intention had been to create a pilgrimage site, and his plan was successful. ${ }^{23}$ Even though Church authorities knew at least since 1312 that the 'miraculous Host of Korneuburg' had been a fake and that the Jews had been innocent, pilgrimages to the chapel built in the place of Zerkel's house survived until well into the baroque period. ${ }^{24}$

There seem to have been no repercussions from the secular authorities either. Although the Habsburg dukes of Austria were usually quick to mete out punishment for attacks against 'their' Jews, none of the surviving sources mention any kind of ducal retribution for the fact that the citizens of Korneuburg had murdered Duke Rudolf III's Jewish subjects. Nevertheless, Ambrose complained that the Duke tried to expedite the proceedings and to prevent the inhabitants of Korneuburg from testifying about the miracles which the desecrated Host wafer had allegedly worked. Those complaints suggest that

22 The priest in question was probably the aforementioned Konrad, vicar of Leobersdorf, because he was the only clergyman among the witnesses who claimed that he had had prior knowledge about the Jews of Korneuburg buying a Host wafer from a Christian. Wiedl, 'The Host on the Doorstep', pp. 321-22.

${ }^{23}$ On the development of Christian cult traditions at the sites of alleged Jewish sacrilege, see Merback, Pilgrimage \& Pogrom.

${ }^{24}$ Stelzer, 'Am Beispiel Korneuburg', pp. 337-39. 
Rudolf III at least attempted to limit the impact that the events might have on the rest of the Jewish population in Austria. ${ }^{25}$

The Korneuburg incident allows rare insights into the precarious coexistence of Jews and Christians in a small town: even though Jews had been living peacefully among the Christian inhabitants for at least a few decades and Zerkel was clearly of high social standing, planting fabricated evidence of a Host allegedly desecrated by Jews was enough to trigger a violent outburst that was not carried out or encouraged by the authorities, but rather by the inhabitants themselves. The priest who orchestrated the incident chose the Jews as the most 'attractive' target, and the fact that his ploy was successful clearly illustrates how volatile the relations between Jews and Christians could be even after a relatively long period of peaceful coexistence.

A similar accusation in the following year, 1306, led to anti-Jewish outbreaks in the town of St Pölten. Again, the anti-Jewish violence was carried out by the citizens, that is, the people in whose direct vicinity the Jews had lived peacefully until then. This time, however, the Duke himself interfered and severely punished the town for attacking a group that was under his special protection, although his reasons were political and most likely had little to do with the Jews themselves. ${ }^{26}$

Accusations of Host desecration were not limited to Jews, and Christian accomplices make frequent appearances even in accounts of Jewish attacks against the Eucharist, although the focus in these cases tends to be on the Jews. ${ }^{27}$ A particularly drastic example is the story of an evil Christian peasant who stole a Host wafer in Vienna in 1306: when he went to a Jew's house with the intention of selling the Host to the Jews, he found himself miraculously immobilized and tried to get rid of the Host wafer by placing it in a jug that was standing by the Jew's door. Soon, the Host began to cry and wail like a child, and the Christians who found it assumed that it had been stolen and desecrated by the Jewish inhabitants of the house. Only Duke Rudolf's personal interference saved the Jews from being lynched by the crowd, and it is rather

25 Brugger, 'Von der Ansiedlung', pp. 214-16; Lotter, 'Hostienfrevelvorwurf und Blutwunderfälschung', pp. 560-61; Stelzer, 'Am Beispiel Korneuburg', pp. 332-33.

${ }^{26}$ St Pölten was not under ducal rule, but under the rule of the Bishop of Passau. Therefore, Rudolf III used the Bishop's failure to protect the Jews as justification for his interference on behalf of 'his' Jews, thus emphasizing his authority over all Austrian Jews and expanding his influence within the jurisdiction of another town lord. Brugger and Wiedl, Regesten zur Geschichte, I, 154-55, no. 145, p. 155, no. 146; Lohrmann, Judenrecht und Judenpolitik, pp. 118-20.

27 Treue, 'Schlechte und gute Christen', pp. 99-105; Cluse, 'Blut ist im Schuh', pp. 375-77. 
telling that the chronicler, who may have been the aforementioned Ambrose of Heiligenkreuz himself, vehemently criticized the Duke for saving 'his beloved Jews' even though his own account of the events leaves no doubt that the Christian peasant was the only culprit and that the Jews were not involved in the theft of the Host at all. ${ }^{28}$

However, the first outbreaks of anti-Jewish violence during the fourteenth century seem to have had no impact on Jewish business life in Austria. Obviously, events like the Korneuburg persecution were seen as isolated, local incidents that did not change the overall status of Jews in society. Still, the belief in miraculous Host wafers desecrated by Jews was spreading among the Christian population, and this development posed a growing threat to the safety of the Austrian Jews in the future. ${ }^{29}$

It is therefore hardly surprising that the first widespread persecution of Jews in Austria happened after another case of alleged Host desecration. In 1338, the discovery of a bloodstained Host wafer in front of a Jewish house in the small Lower Austrian town of Pulkau led not only to the murder of the Jewish population of the town, but also to the ensuing persecution of Jews in other places in Lower Austria and in the neighbouring countries of Bohemia and Moravia. ${ }^{30}$ It has been speculated that the Pulkau persecution itself might have been triggered by the 'Armleder' persecutions, which had started in 1336 as a social uprising of peasants and lower-class townspeople under the leadership of an impoverished knight in Franconia and heavily affected the Jewish communities in southern Germany. ${ }^{31}$ There seems to have been no direct connection to Austria, and the 'Armleder' uprisings had been crushed by the authorities by 1338 , but news of the events had definitely reached the local Austrian population. ${ }^{32}$

${ }^{28}$ Brugger and Wiedl, Regesten zur Geschichte, I, 156-57, no. 147. The story was most likely recorded after Duke Rudolf's death in 1307; on the question of authorship, see Stelzer, 'Am Beispiel Korneuburg', pp. 328-29, 344.

${ }^{29}$ On the general impact of anti-Jewish violence and anti-Jewish rhetoric on Jewish life, see Elukin, Living Together, Living Apart, pp. 89-100.

${ }^{30}$ Brugger, 'Von der Ansiedlung', pp. 216-19; Brugger and Wiedl, Regesten zur Geschichte, I, 343-51, nos. 448-56; The Nuremberg Memorbuch lists thirty-one 'blood cities' in Austria, Bohemia, and Moravia, although the mention of Passau in the list seems to pertain to the Deggendorf persecution of 1337 in Bavaria, not the Pulkau persecution of 1338. Brugger and Wiedl, Regesten zur Geschichte, I, 348-49, no. 455; Avneri, Germania Judaica, II.2, 647-48.

${ }^{31}$ Lotter, 'Hostienfrevelvorwurf und Blutwunderfälschung', pp. 561-71; Müller, 'Erez gezerah', pp. 255-56.

32 Rubin, 'Imagining the Jew', pp. 188-89. 
Therefore, they might very well have had an influence - accusations of Host desecration had initially not been a factor in the 'Armleder' attacks against Jews, but they developed quickly in their wake. ${ }^{33}$

The Pulkau persecution constitutes the first time in Austria that a local incident caused widespread violence against the Jewish population. It alarmed both the Duke and the ecclesiastical leaders up to the Pope himself, who ordered the Bishop of Passau to investigate the matter and to punish the culprits if the Jews were found to be innocent of Host desecration. ${ }^{34}$ Still, this persecution made it obvious just how little protection the authorities were able to give the Jews, especially those in more remote places. After Pulkau, Jewish settlement seems to have come to an end in some of the smaller towns, and more Jews can be traced in the larger cities where their communities were better protected. However, the paucity of written sources on Jewish presence in small towns makes it difficult to estimate the actual impact of the persecution on this development. To give just one example: the municipal council of the small town of Eggenburg had proudly called two Jewish businessmen 'our Jews of Eggenburg' in 1311, yet the Jews of the town fell victim to the Pulkau persecution in 1338, and there is no further evidence of Jewish inhabitants in Eggenburg for several decades. ${ }^{35}$ However, in the decades after 1338 Jews returned to some of the towns that had been hit by the persecution - for example, three Jews from the same town of Eggenburg appear in a business charter in $1366 .{ }^{36}$ This suggests that the small rural Jewish settlements were not entirely 'wiped out' as had previously been assumed by some scholars. ${ }^{37}$ Indeed, even after 1338 life in a small countryside town must have been attractive enough for some Jews to risk leaving the above-mentioned protection of a big Jewish community. Even rich and influential Jews like the scholar and businessmen Hetschel of Herzogenburg

${ }^{33}$ Lotter, 'Hostienfrevelvorwurf und Blutwunderfälschung', p. 567.

${ }^{34}$ Brugger and Wiedl, Regesten zur Geschichte, I, 339-41, nos. 443-44; Merback, Pilgrimage \& Pogrom, pp. 77-78. Pope Benedict XII explicitly mentioned the events of Korneuburg in his letter to the Bishop of Passau and pointed out that the alleged Jewish Host desecration of 1305 had been staged by a priest. Several chroniclers and theologians also referred to the events of Korneuburg in their rapports on the Pulkau persecutions; see Brugger and Wiedl, Regesten zur Geschichte, I, 346-47, no. 452, 349-51, no. 456.

35 Brugger and Wiedl, Regesten zur Geschichte, I, 179-80, no. 178; Maimon, Breuer, and Guggenheim, Germania Judaica, III.1, 284-85.

36 Brugger and Wiedl, Regesten zur Geschichte, III, 20, no. 1162.

37 Wiedl, “'Lazarus and Abraham”', pp. 660-62. 
sometimes chose to live in a place where they and their household were surrounded almost exclusively by Christians. ${ }^{38}$

Unlike prior, localized outbreaks of anti-Jewish violence, the Pulkau persecution was the first to also have a heavy impact on Jewish business activities. There is a noticeable decline in the number of charters on Jewish business during the years directly following 1338. A Christian business charter from January 1339 mentions a loan transaction with the Jewess Plume of Klosterneuburg (the most important Jewish businesswoman of her time); the document explicitly states the possibility that it might not be necessary to repay the loan because of the 'turmoil that is happening among the Jews', which most likely means the aftermath of the persecution. ${ }^{39}$ The citizenry of Vienna found another way to profit from the danger to the Jewish population: they forced the Jewish community to accept a severe reduction of interest rates on Jewish loans for Viennese citizens in return for protection. Both the Jewish community leaders and the Austrian Dukes Albrecht II and Otto were forced to agree in order to keep the Viennese Jews safe. ${ }^{40}$

The financial aspect of the persecution was obvious to many contemporaries as well. Some of the numerous Christian narrative sources state that 'greed for Jewish property' was the real motivation of the persecutors, although most of these texts do not mean to express any sympathy for the Jews, but to point out that they should have been persecuted for religious rather than for financial reasons. ${ }^{41}$ Considering that these annals and chronicles were written by members of the clergy, the matter illustrates the stark contrast between the official papal position regarding the Jews (which forbade religiously motivated persecution) and the open hostility that local clergymen often expressed towards them. ${ }^{42}$

In spite of the citizens' readiness to either join into the persecutions or at least to use them to their advantage, Jewish life in Austrian towns seems to have returned to normality fairly quickly in the years following 1338. As opposed to many other territories in the Holy Roman Empire, there were hardly any

${ }^{38}$ Grahammer, 'Hetschel von Herzogenburg'; Brugger, 'Small Town, Big Business'; Brugger, 'Hetschel und wer noch?'.

39 Brugger and Wiedl, Regesten zur Geschichte, II, 9, no. 457.

${ }^{40}$ Brugger and Wiedl, Regesten zur Geschichte, I, 336-38, nos. 439-40; Brugger, 'Between a Rock and a Hard Place', pp. 194-95.

${ }^{41}$ Brugger, 'Von der Ansiedlung', pp. 218-20.

${ }^{42}$ Cohen, Under Crescent and Cross, pp. 37-41; Pakter, Medieval Canon Law; Schreckenberg, Die christlichen Adversus-Judaeos-Texte (11.-13. Jh.), pp. 244-45; Schreckenberg, Die christlichen Adversus-Judaeos-Texte (13.-20. Jh.), pp. 175-76. 
persecutions during the time of the plague in Austria. In contrast to the events of 1338, Duke Albrecht II was able to maintain the peace, with the exception of an attack against the Jews in Krems in 1349, for which he punished the citizens heavily. ${ }^{43}$ It is important to keep in mind that the massive outbreaks of anti-Jewish violence in the Holy Roman Empire during the time of the plague, especially in the later stages, were premeditated and orchestrated persecutions rather than spontaneous violent outbreaks carried out by a fearful or traumatized mob. Municipal authorities or even territorial rulers were the driving forces behind these attacks. ${ }^{44}$ Therefore, the strong and efficient ducal protection in Austria made sure that the Austrian Jews survived these critical times almost completely unscathed.

Still, the situation of the Jewish population gradually became more difficult in the course of the second half of the fourteenth century. The number of surviving business charters is larger than ever before, and this type of source is - unsurprisingly - still free from the expression of anti-Jewish sentiments, but they indicate that ducal protection of Jewish business was weakening. ${ }^{45}$ The persecutions had demonstrated to the Christian population that the Jews were vulnerable and that the protection they received from the dukes had its limitations - but more importantly, the dukes themselves were beginning to lose interest in protecting Jewish business as the economic relevance of Jewish moneylenders waned. ${ }^{46}$

At the same time, the social markers of the Jewish loan clientele were shifting. The surviving sources indicate that a growing number of Christian clients now came from lower classes, no longer from the nobility and the urban elites. ${ }^{47}$ This might partly be due to the fact that financial transactions between Jews and lower-class Christians were now more likely to be recorded because the use of Judenbücher (libri Iudeorum), which documented Jewish loans, became more frequent during the second half of the fourteenth century. ${ }^{48}$ However, it

${ }^{43}$ Brugger and Wiedl, Regesten zur Geschichte, II, 97-98, nos. 646-47; Brugger, 'Between a Rock and a Hard Place', pp. 196-97.

${ }^{44}$ Müller, 'Erez gezerah', pp. 256-57; Graus, Pest - Geißler - Judenmorde, pp. 227-48; Toch, Die Juden im mittelalterlichen Reich, pp. 62-63.

45 Brugger, 'Small Town, Big Business', p. 677.

46 Wiedl, 'Jews and the City', p. 301.

47 Toch, 'Economic Activities of German Jews', pp. 197-99; Wenninger, Man bedarfkeiner Juden mehr, pp. 226-30.

${ }^{48}$ Brugger, 'Von der Ansiedlung', pp. 161-62; Peter, 'Judenbücher als Quellengattung', pp. 307-19. 
may also indicate a gradual decline in the social status of the majority of the Jewish population, especially since Christian credit business was growing steadily at the same time, which diminished the importance of Jewish moneylenders. ${ }^{49}$ Municipal communities tried to gain greater influence over 'their' Jews, although these attempts were never particularly successful in Austria because of the strong ducal authority. ${ }^{50}$ Still, municipal charters clearly illustrate the attempt to limit Jewish economic influence, for example, by placing restrictions on Jewish pawnbroking. ${ }^{51}$ Municipal legal texts from the second half of the fourteenth century also contain open animosity towards Jews. The most famous example is the Wiener Stadtbuch, a private collection of municipal legal customs, which states that 'the accursed Jews have much better rights towards Christians than the Christians have towards the Jews.'52

In spite of the growing pressure on Jewish business during the second half of the fourteenth century, the quantity of surviving sources indicates that this pressure did not lead to an immediate decline in the amount of Jewish business transactions in Austria, just like the increase in ecclesiastical anti-Jewish rhetoric does not seem to have had much direct impact on everyday JewishChristian relations and did not (yet) endanger the lives and safety of the Austrian Jewry in its entirety. ${ }^{53}$ The gradual erosion of ducal protection of Jewish property meant a growing economic risk to the Jewish financial elite, but the second half of the century was still mostly free from physical antiJewish violence. Of course, Jews were not immune from the general occasional violence that was a standard factor of everyday life in towns and cities. ${ }^{54} \mathrm{~A}$ collection of Urfehdebriefe (charters of truce) from the year 1386 in the Municipal Archives of Krems contains a charter by one Lorenz Reyban from the small

${ }^{49}$ Gilomen, Juden in den spätmittelalterlichen Städten des Reichs, p. 28; Brugger, 'Between a Rock and a Hard Place', p. 199.

50 Toch, 'Jüdische Geldleihe', pp. 89-90; Wenninger, 'Juden und Christen', pp. 288-89.

${ }^{51}$ Wiedl, 'Jews and the City', pp. 291-92.

${ }^{52}$ Brugger and Wiedl, Regesten zur Geschichte, II, 232, no. 929; Magin, 'Wie es umb der iuden recht stet', pp. 102-05, 371-72. The complaint is directed towards the Statute of the Market, which protected Jewish pawnbrokers in case they unknowingly accepted stolen goods as pledge. Toch, The Economic History of European Jews, p. 211.

53 Brugger, 'Between a Rock and a Hard Place', pp. 199-200; Lohrmann, Judenrecht und Judenpolitik, pp. 264-81. On the controversial question of the social impact of antiJewish stereotypes in sermons, see Cluse, 'Blut ist im Schuh', pp. 373-75; Mikosch, 'Nichts als Diskurse', pp. 253-54, 267-68.

${ }^{54}$ Elukin, Living Together, Living Apart, pp. 90-91. 
Lower Austrian town of Wösendorf, who had been punished by the judge and the council of Krems for threatening and beating several Jews from Krems. In the charter, he promised 'not to do such things to any Jew again' and not to harbour any ill will or enmity towards any of the involved parties on pain of having his eyes gouged out, which was the standard punishment for breaking a truce and can also be found in other charters from the same collection that had nothing to do with Jews. The charter does not mention the perpetrator's reasons for attacking the Jews in the first place - anti-Jewish resentment may of course have played a role, but it had no bearing on the way the incident was dealt with. The iudex Iudeorum (a Christian judge responsible for cases between Jewish and Christian parties) of Krems was not even involved, which indicates that the municipal authorities did not consider it a specifically 'Jewish' matter. ${ }^{55}$

Social and cultural contacts between Jews and Christians remained a daily reality, and especially the Jewish elite kept sharing the lifestyle and taste of the corresponding Christian classes to a remarkable degree. ${ }^{56}$ The number of surviving sources on Jewish-Christian business transactions from the second half of the fourteenth century is much higher than that from the first half of the century, and while this development is mostly owed to the aforementioned general rise in written sources during that timeframe, it also indicates that the persecutions from the middle of the century had had no lasting impact on the quantitative development of everyday business contacts.

Many questions about the situation of the Austrian Jews during the last decades of the fourteenth century remain unanswered for the time being because the sources from this timeframe have not yet been researched in their entirety. ${ }^{57}$ For the same reason, it is not entirely clear yet how exactly Jewish-Christian relations developed in the decades immediately leading up to the catastrophe of the Austrian Jewry in 1420/21 - a catastrophe which, unlike the events in Korneuburg and Pulkau, was not brought about by next-door neighbours,

55 Brugger and Wiedl, Regesten zur Geschichte, III, 422-23, no. 1857.

${ }^{56}$ Keil, 'Kulicht schmalz und eisen gaffel', p. 66; Wiedl, 'Jews and the City', pp. 277-78.

57 The collection and evaluation of these sources is an ongoing project at the Institute for Jewish History in Austria. So far, charters and historiographic sources up to the year 1386 have been published (Brugger and Wiedl, Regesten zur Geschichte, I; Brugger and Wiedl, Regesten zur Geschichte, II; and Brugger and Wiedl, Regesten zur Geschichte, III); volume IV, which covers the period 1387-1404, is in preparation. Current research is focused on the source material from the early fifteenth century. Since many of these sources have never been published or even used in research before, they are likely to yield new information on the status and development of Jewish-Christian relations in late medieval Austria. 
but for the first time by the Austrian Duke himself. In the course of the 'Vienna Gesera' (named after the Yiddish account of the persecution ${ }^{58}$ ), Duke Albrecht $\mathrm{V}$ had hundreds of Austrian Jews captured and killed while others reportedly committed suicide to escape forced baptizing. Jewish property was seized; the surviving Jews were expelled from the duchy of Austria. ${ }^{59}$

Based on the sources which are currently known, we have to conclude that in spite of the growing difficulties the Austrian Jews had been facing from the midfourteenth century onwards, they were still able to live among the Christian citizens in relative safety up to $1420 / 21$. Localized outbreaks of anti-Jewish riots, such as the attacks against the Viennese Jews in 1406, which were spearheaded by students of the University of Vienna, ${ }^{60}$ do not seem to have affected the overall, often uneasy but mostly non-violent nature of Jewish-Christian interaction in Austrian towns. It took a drastic change in the duke's policy whose motivation is the subject of an ongoing debate among researchers - to bring about what several centuries of latent and/or manifest anti-Jewish resentment among the Christian population had not managed: an existential threat to Jewish life as a whole in medieval Austria.

${ }^{58}$ For the text of the Gesera, see Goldmann, Das Judenbuch der Scheffstrasse, pp. 125-32.

59 On the events and general background of the Gesera, see Brugger, 'Von der Ansiedlung,' pp. 221-24; Maimon, Breuer, and Guggenheim, Germania Judaica, III.3, 1986-88; Keil, 'Bet haKnesset, Judenschul', pp. 73-74; Lohrmann, Die Wiener Juden im Mittelalter, pp. 155-73.

${ }^{60}$ Brugger, 'Von der Ansiedlung', p. 221. 


\section{Works Cited}

\section{Secondary Works}

Avneri, Zvi, ed., Germania Judaica, II.1, 2: Von 1238 bis zur Mitte des 14. Jahrhunderts (Tübingen: J. C. B. Mohr, 1968)

Brugger, Eveline, '... hat ein hebraisch zettel dabey: Der Umgang mit jüdisch-christlichen Geschaftsurkunden im spätmittelalterlichen Österreich', in Abrahams Erbe: Konkurrenz, Konflikt und Koexistenz der Religionen im europäischen Mittelalter, ed. by Ludger Lieb, Klaus Oschema, and Johannes Heil, Das Mittelalter, 2 (Berlin: Walter de Gruyter, 2015) pp. 421-36

—_, 'Urkunden zum jüdischen Kreditgeschäft im mittelalterlichen Österreich', in Verschriftlichung und Quellenüberlieferung: Beiträge zur Geschichte der Juden und der jüdisch-christlichen Beziehungen im spätmittelalterlichen Reich (13./14. Jahrhundert), ed. by Alfred Haverkamp and Jörg R. Müller (Peine: Verlag Hahnsche Buchhandlung, 2014), pp. 65-82

_- 'Between a Rock and a Hard Place: Rulers, Cities, and "their" Jews in Austria During the Persecutions of the Fourteenth Century', in Slay Them Not: Jews in Medieval Christendom, ed. by Merrall Price and Kristine Utterback (Leiden: Brill, 2013), pp. 189-200

_ - 'Hetschel und wer noch? Anmerkungen zur Geschichte der Juden in Herzogenburg im Mittelalter', in 900 Jahre Stift Herzogenburg: Aufbrüche - Umbrüche - Kontinuität; Tagungsband zum wissenschaftlichen Symposium vom 22.-24. September 2011, ed. by Günter Katzler and Victoria Zimmerl-Panagl (Innsbruck: StudienVerlag, 2013), pp. 119-37

_ - 'Small Town, Big Business: A Wealthy Jewish Moneylender in the Austrian Countryside', in Rural Space in the Middle Ages and Early Modern Age: The Spatial Turn in Premodern Studies, ed. by Albrecht Classen, Fundamentals of Medieval and Early Modern Culture, 9 (Berlin: Walter de Gruyter, 2012), pp. 673-84

—_, 'Von der Ansiedlung bis zur Vertreibung: Juden in Österreich im Mittelalter', in Eveline Brugger and others, Geschichte der Juden in Österreich, 2nd edn (Wien: Ueberreuter, 2013), pp. 123-227, 585-96

Brugger, Eveline, and Birgit Wiedl, Regesten zur Geschichte der Juden in Österreich im Mittelalter, I: Von den Anfängen bis 1338 (Innsbruck: StudienVerlag, 2005), <https:// e-book.fwf.ac.at/o:55>

—, Regesten zur Geschichte der Juden in Österreich im Mittelalter, II: 1339-1365 (Innsbruck: StudienVerlag, 2010), <https://e-book.fwf.ac.at/o:58>

—, Regesten zur Geschichte der Juden in Österreich im Mittelalter, III: 1366-86 (Innsbruck: Studien Verlag, 2015), <http://e-book.fwf.ac.at/o:766>

__ , '...und ander frume leute genuch, paide christen und juden: Quellen zur christlichjüdischen Interaktion im Spätmittelalter', in Räume und Wege: Jüdische Geschichte im Alten Reich 1300-1800, ed. by Rolf Kießling and others, Colloquia Augustana, 25 (Berlin: Akademie Verlag, 2007), pp. 285-305 
Chazan, Robert, Reassessing Jewish Life in Medieval Europe (Cambridge: Cambridge University Press, 2010)

Cluse, Christoph, 'Blut ist im Schuh: Ein Exempel zur Judenverfolgung des "Rex Armleder"', in Liber Amicorum necnon et amicarum: Für Alfred Heit; Beiträge zur mittelalterlichen Geschichte und geschichtlichen Landeskunde, ed. by Friedhelm Burgard, Christoph Cluse, and Alfred Haverkamp, Trierer Historische Forschungen, 28 (Trier: Verlag Trierer Historische Forschungen, 1996), pp. 371-92

Cohen, Mark R., Under Crescent and Cross: The Jews in the Middle Ages (Princeton, NJ: Princeton University Press, 1994)

Elukin, Jonathan, Living Together, Living Apart: Rethinking Jewish-Christian Relations in the Middle Ages (Princeton, NJ: Princeton University Press, 2007)

Erb, Rainer, 'Zur Erforschung der europäischen Ritualmordbeschuldigungen', in Die Legende vom Ritualmord: Zur Geschichte der Blutbeschuldigung gegen Juden, ed. by Rainer Erb (Berlin: Metropol-Verlag, 1993), pp. 9-16

Gilomen, Hans-Jörg, Juden in den spätmittelalterlichen Städten des Reichs: Normen Fakten - Hypothesen, Kleine Schriften des Arye Maimon-Instituts, 11 (Trier: Eigenverlag des Arye Maimon-Instituts, 2009)

Goldin, Simha, Jewish Women in Europe in the Middle Ages: A Quiet Revolution (Manchester: Manchester University Press, 2011)

Goldmann, Artur, Das Judenbuch der Scheffstrasse zu Wien (1389-1420), Quellen und Forschungen zur Geschichte der Juden in Deutsch-Österreich, 1 (Wien: Wilhelm Braumüller, 1908)

Grahammer, Hannelore, 'Hetschel von Herzogenburg und seine Familie', in Studien zur Geschichte der Juden in Österreich, ed. by Martha Keil and Klaus Lohrmann (Wien: Böhlau, 1994), pp. 100-20

Graus, František, Pest - Geißler - Judenmorde: Das 14. Jahrhundert als Krisenzeit, 2nd edn (Göttingen: Vanderhoeck \& Ruprecht, 1988)

Holtmann, Annegret, 'Jewish Moneylending as Reflected in Medieval Account Books: The Example of Vesoul', in The Jews of Europe in the Middle Ages (Tenth to Fifteenth Centuries), ed. by Christoph Cluse (Turnhout: Brepols, 2004), pp. 306-15

Jordan, William Chester, 'Jews on Top: Women and the Availability of Consumption Loans in Northern France in the Mid-Thirteenth Century', Journal of Jewish Studies, 29 (1978), 39-56

Keil, Martha, 'Bet haKnesset, Judenschul: Die mittelalterliche Synagoge als Gotteshaus, Amtsraum und Brennpunkt sozialen Lebens', Wiener Jahrbuch für jüdische Geschichte, 4 (1999/2000), 71-89

_ - 'Kulicht schmalz und eisen gaffel — Alltag und Repräsentation bei Juden und Christen im Spätmittelalter', Aschkenas: Zeitschrift für Geschichte und Kultur der Juden, 14.1 (2004), 51-81

— - 'Nähe und Abgrenzung: Die mittelalterliche Stadt als Raum der Begegnung', in Nicht in einem Bett. Juden und Christen in Spätmittelalter und Frühneuzeit, ed. by Institut für Geschichte der Juden in Österreich (Wien: rema print, 2005), pp. 2-8, <http://www.injoest.ac.at/files/jme_2005.pdf> 
Langmuir, Gavin, Toward a Definition of Antisemitism (Berkeley: University of California Press, 1990)

Lohrmann, Klaus, Judenrecht und Judenpolitik im mittelalterlichen Österreich (Wien: Böhlau, 1990)

— Die Wiener Juden im Mittelalter (Berlin: Philo, 2000)

Lotter, Friedrich, 'Hostienfrevelvorwurf und Blutwunderfälschung bei den Judenverfolgungen von 1298 ("Rintfleisch") und 1336-38 ("Armleder")', in Fälschungen im Mittelalter, v: Fingierte Briefe. Frömmigkeit und Fälschung. Realienfälschungen, MGH Schriften, 33.5 (Hannover: Hahn, 1988), pp. 533-83

Magin, Christine, 'Wie es umb der iuden recht stet': Der Status der Juden in spätmittelalterlichen deutschen Rechtsbüchern (Göttingen: Wallstein Verlag, 1999)

Maimon, Arye, Mordechai Breuer, and Yacov Guggenheim, eds, Germania Judaica, III.1, 2, 3: 1350-1519 (Tübingen: J. C. B. Mohr, 1987-2003)

Merback, Mitchell B., Pilgrimage \& Pogrom: Violence, Memory, and Visual Culture at the Host-Miracle Shrines of Germany and Austria (Chicago: University of Chicago Press, 2012)

Mikosch, Gunnar, 'Nichts als Diskurse: Juden in den frühen mittelhochdeutschen Predigten des 12. und 13. Jahrhunderts', in Historische Diskursanalysen: Genealogie, Theorie, Anwendungen, ed. by Franz X. Eder (Wiesbaden: VS Verlag für Sozialwissenschaften, 2006), pp. 253-69

Müller, Jörg, 'Erez gezerah - "Land of Persecution": Pogroms against the Jews in the regnum Teutonicum from c. 1280 to 1350', in The Jews of Europe in the Middle Ages (Tenth to Fifteenth Centuries), ed. by Christoph Cluse (Turnhout; Brepols, 2004), pp. 245-60

Pakter, Walter, Medieval Canon Law and the Jews, Münchner Universitätsschriften, Abhandlungen zur rechtswissenschaftlichen Grundlagenforschung, 68 (Ebelsbach: Verlag Rolf Gremer, 1988)

Patschowksy, Alexander, 'Das Rechtsverhältnis der Juden zum deutschen König (9.-14. Jahrhundert): Ein europäischer Vergleich', Zeitschrift der Savigny-Stiftung für Rechtsgeschichte, Germanistische Abteilung, 110 (1993), 331-71

Peter, Thomas, 'Judenbücher als Quellengattung und die Znaimer Judenbücher: Typologie und Forschungsstand', in Räume und Wege: Jüdische Geschichte im Alten Reich 1300-1800, ed. by Rolf Kießling and others, Colloquia Augustana, 25 (Berlin: Akademie Verlag, 2007), pp. 307-34

Rubin, Miri, Corpus Christi: The Eucharist in Late Medieval Culture (Cambridge: Cambridge University Press, 1991)

— Gentile Tales: The Narrative Assault on Late Medieval Jews (New Haven: Yale University Press, 1999)

- 'Imagining the Jew: The Late Medieval Eucharistic Discourse', in In and Out of the Ghetto: Jewish-Gentile Relations in Late Medieval and Early Modern Germany, ed. by R. Po-chi Hsia and Hartmut Lehmann (Cambridge: Cambridge University Press, 1995), pp. 177-208

Schreckenberg, Heinz, Die christlichen Adversus-Judaeos-Texte (11.-13. Jh.): Mit einer Ikonographie des Judenthemas bis zum 4. Laterankonzil, Europäische Hochschulschriften, Reihe XXIII Theologie, 335, 2nd edn (Frankfurt a. M.: Peter Lang, 1991) 
- Die christlichen Adversus-Judaeos-Texte und ihr literarisches und historisches Umfeld (13.-20. Jh.), Europäische Hochschulschriften, Reihe XXIII Theologie, 497 (Frankfurt a. M.: Peter Lang, 1994)

Stelzer, Winfried, 'Am Beispiel Korneuburg: Der angebliche Hostienfrevel österreichischer Juden von 1305 und seine Quellen', in Österreich im Mittelalter: Bausteine zu einer revidierten Gesamtdarstellung, ed. by Willibald Rosner, Studien und Forschungen aus dem Niederösterreichischen Institut für Landeskunde, 26 (St. Pölten: Selbstverlag des Niederösterreichischen Instituts für Landeskunde, 1999), pp. 309-48

Toch, Michael, 'Economic Activities of German Jews in the Middle Ages', in Wirtschaftsgeschichte der mittelalterlichen Juden, ed. by Michael Toch, Schriften des Historischen Kollegs: Kolloquien, 71 (München: Oldenbourg, 2008), pp. 181-210

- The Economic History of European Jews: Late Antiquity and Early Middle Ages, Études sur le Judaïsme Médiéval, 56 (Leiden: Brill, 2013)

— Die Juden im mittelalterlichen Reich, Enzyklopädie deutscher Geschichte, 44, 2nd edn (München: Oldenburg, 2003)

_ - 'Jüdische Geldleihe im Mittelalter', in Geschichte und Kultur der Juden in Bayern, ed. by Manfred Treml and Josef Kirmeier (München: K. G. Saur, 1988), pp. 85-94

Treue, Wolfgang, 'Schlechte und gute Christen: Zur Rolle von Christen in antijüdischen Ritualmord- und Hostienschändungslegenden', Aschkenas: Zeitschrift für Geschichte und Kultur der Juden, 2.1 (1992), 95-116

Wenninger, Markus, 'Juden und Christen als Geldgeber im hohen und späten Mittelalter', in Die Juden in ibrer mittelalterlichen Umwelt, ed. by Alfred Ebenbauer and Klaus Zatloukal (Wien: Böhlau, 1991), pp. 280-99

_-, Man bedarf keiner Juden mehr: Ursachen und Hintergründe ibrer Vertreibung aus den deutschen Reichsstädten im 15. Jahrhundert (Wien: Böhlau, 1981)

_ - 'Nicht in einem Bett — aber doch auf einer Hochzeit: Zur Teilnahme von Christen an jüdischen Festen im Mittelalter', in Nicht in einem Bett: Juden und Christen in Spätmittelalter und Frühneuzeit, ed. by Institut für Geschichte der Juden in Österreich (Wien: rema print, 2005), pp. 10-17, <http://www.injoest.ac.at/files/jme_2005.pdf> Wiedl, Birgit, 'The Host on the Doorstep: Perpetrators, Victims, and Bystanders in an Alleged Host Desecration in Fourtheenth-Century Austria', in Crime and Punishment in the Middle Ages and Early Modern Times, ed. by Albrecht Classen and Connie L. Scarborough, Fundamentals of Medieval and Early Modern Culture, 7 (Berlin: Walter de Gruyter, 2012), pp. 299-345

_- 'Jews and the City: Parameters of Jewish Urban Life in Late Medieval Austria', in Urban Space in the Middle Ages and the Early Modern Age, ed. by Albrecht Classen, Fundamentals of Medieval and Early Modern Culture, 4 (Berlin: Walter de Gruyter, 2009), pp. 273-308

__, 'Juden in österreichischen seriellen Quellen des 14. Jahrhunderts', in Verschriftlichung und Quellenüberlieferung: Beiträge zur Geschichte der Juden und der jüdisch-christlichen Beziehungen im spätmittelalterlichen Reich (13./14. Jahrhundert), ed. by Alfred Haverkamp and Jörg R. Müller (Peine: Verlag Hahnsche Buchhandlung, 2014), pp. 123-45 
__ ' “Lazarus and Abraham, our Jews of Eggenburg”: Jews in the Austrian Countryside in the Fourteenth Century', in Rural Space in the Middle Ages and Early Modern Age: The Spatial Turn in Premodern Studies, ed. by Albrecht Classen, Fundamentals of Medieval and Early Modern Culture, 9 (Berlin: Walter de Gruyter, 2012), pp. 639-72 Yuval, Israel, Two Nations in Your Womb: Perceptions of Jews and Christians in Late Antiquity and the Middle Ages, trans. by Barbara Harshav and Jonathan Chipman (Berkeley: University of California Press, 2006) 